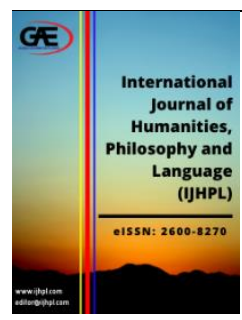

International Journal of Humanities, Philosophy and Language (IJHPL)

\title{
REQUIREMENTS OF LEARNING ARABIC LANGUAGE AMONG ISLAMIC FINANCIAL STUDENTS
}

\author{
Ahmad Farid Fadhli Mustafa ${ }^{*}$, Muhammad Anas Al Muhsin ${ }^{2}$
}

1 Arabic Language Department, Centre for Languages and Foundation Studies (CELFOS), Universiti Sultan Azlan Shah, Kuala Kangsar, Perak, Malaysia.

Email: farid@usas.edu.my

2 Department of Modern Languages, Faculty of Languages and Communications, Universiti Pendidikan Sultan Idris, Tanjung Malim, Perak, Malaysia.

Email: anas@fbk.upsi.edu.my

* Corresponding Author

\section{Article Info:}

\section{Article history:}

Received date: 05.03 .2020

Revised date: 09.03.2020

Accepted date: 13.03 .2020

Published date: 15.03.2020

\section{To cite this document:}

Mustafa, A. F. F., \& Al Muhsin, M. A. (2020). Requirements of Learning Arabic Language among Islamic Financial Students. International Journal of Humanities, Philosophy and Language, 3 (9), 24-35.

DOI: $10.35631 /$ IJHPL.39004.

\begin{abstract}
:
The issue of Arabic language proficiency among students of Higher Education Institutions (HEIs) is a concern as the majority of students are still poor at mastering and understanding Arabic terms. The Arabic language learning and teaching scenario are based solely on the basic courses taken to qualify for the graduation process. The purpose of this study is to identify the Arabic language learning needs among Islamic Finance students in USAS. The study was a public survey of 60 undergraduate students in Islamic Finance using a self-administered questionnaire conducted by a researcher who has been certified by an expert in the field. The research questionnaire was divided into 3 main sections: identifying the respondents' background, students' knowledge of the Arabic language and their Arabic language learning needs. This data is analyzed using descriptive statistics of frequency and percentage only. The findings showed that Arabic knowledge of Islamic finance course information had the highest frequency and percentage of $n=$ 35; 58.3\%. Whereas the Arabic language learning needs show the highest frequency and percentage are related to the manual or module of learning Arabic for $n=45 ; 75 \%$. In conclusion, the findings of this study are proposed as a guide to developing the development of Arabic language modules for a more robust study in Malaysian HEIs.
\end{abstract}

\section{Keywords:}

Arabic for Muamalat, Arabic Requirements, Arabic Specific Purpose, Islamic Finance and Banking 


\section{Introduction}

Muamalat is a procedure or regulation in human relationships to meet their individual needs in accordance with the laws of Allah involving Islamic economic and social fields. Humans need to plan life on earth in the framework of the Quran, as Allah says: "And seek what Allah has provided in the hereafter (retribution and happiness), but do not forget your fate from the world (that is, deeds and pleasures)" [Al-Qasas: 77]. But in our dealings with people, language is an important communicative factor in communicating with one another in order to understand what is required.

In Malaysia, Malay is the official language of this country and it is the identity of the Malay race. However, if viewed the origin of the Malay words of a language other than English, it's a lot permeated by elements of foreign languages such as Arabic, Tamil, Sanskrit, English, Chinese, Tamil, and others. Pabiyah Hajimaming (2010) noted that there were a total of 2,150 Arabic loan words found in the Malay language covering various aspects and fields, such as religious terms, financial terms, noun, verb and others.

At the same time, all sectors need to be prepared regardless of the economic, social and others in order to ease the teaching and learning process according to the latest evolution such as education 4.0, which is innovation and current development. If so, the use of Arabic language is so widespread that there are courses or modules of Arabic language with specific purposes that were previously pioneered by English language learners. Such studies are sociolinguistic studies to study the social relations of Arabic in a particular context in which it may have an impact on customers involved in Islamic banking and finance especially when they conduct business or transactions in selecting banking products and finance.

Therefore, studies on the needs of Arabic language among Islamic finance and banking students have been conducted to look at the vacant areas that can be explored in order to expand Arabic language studies.

\section{Problem Statement}

The knowledge and understanding of Arabic language among students in matters of muamalat is rarely discussed. However, this should not be considered trivial. This is because students who enroll in Islamic finance programs will often serve in the financial and banking sectors after graduation. As such, they will be exposed to the current banking dealings of Islamic products based on current trends. They need to understand the terms or conditions applied when dealing and doing transactions such as loans, savings, charges and so on.

Universiti Sultan Azlan Shah (USAS) was formerly known as Kolej Islam Darul Ridzuan (KISDAR) was established in 1999 by the Islamic Religious Council and Perak Malay Customs and registered with the Perak Islamic Religious Department under the control of the Islamic Religious Schools 1996. Kisdar became the statutory body of the Perak State Government through the Darul Ridzuan Islamic College Enactment (Enactment Number 3 of 2000). On December 19, 2013, His Royal Highness King of Perak Darul Ridzuan Raja Dr. Nazrin Shah Ibni Sultan Azlan Muhibbuddin Shah perfectly officiated the KISDAR upgrade to the Sultan Azlan Shah Islamic University College (KUISAS). On June 10, 2016 Prime Minister, Y.A.B Dato 'Seri Najib Tun Abdul Razak made the official announcement that KUISAS was upgraded to a full-fledged university and was known as Sultan Azlan Shah University (USAS). 
Looking at it, USAS is one of the universities that offers a number of programs in which there are Arabic courses as compulsory courses either at the Diploma level or at the Bachelor's Degree (ISM). Among the programs that use Arabic as a Bachelor's degree course are ISM Counseling [PBA6012: Basic Arabic I \& PBA6022: Basic Arabic II], Islamic Finance ISM [PBA6013: Arabic for Muamalat], Islamic Studies ISM, Syariah ISM Uses and ISM Usuluddin (Hadith) [BAK6163: Al-Lughah Al-Arabiyah I (Nahw), BAK6173: AlLughah Al-Arabiyah II (Sarf) and BAK6183: Al-Lughah Al-Arabiyah III (Balaghah)].

For the Islamic Finance ISM program, students are required to register and pass the PBA6013: Arabic Language for Muamalat course. The basic purpose is to require students to sign up for this Arabic course so that they can learn the special features of the Arabic language and learn to link the words and sentences and students will also be able to write short sentences and communicate in Arabic with a brief and most important conversation about the basics of using the finance term using Arabic language. Therefore, studies on the needs of the Arabic language need to be made from time to time not only in terms of worship (ibadah), tourism and others but also in various exploratory areas, especially in matters involving muamalat.

\section{Research Questions}

Some research questions will be discussed in this study. The questions are as follows:

1) What topics of Arabic course are used in learning?

2) What is Arabic language knowledge among Islamic Finance ISM students?

\section{Research Objective}

This study is based on the following objectives:

1) View topics of Arabic language courses used in learning.

2) Identify Arabic language knowledge among Islamic Finance ISM students.

\section{Literature Review}

The study will look at some previous studies for guidance in conducting the actual study. Based on the research conducted, there has been no study involving Arabic language learning for Muslim students.

However, some activity books, dictionaries, and other muamalat-related books have been written by authors such as Al-Hayah: The Dictionary of the Term Muamalat (2011) authored by Mohd Soberi Awang which briefly describes the terms muamalat used by scholars, classical and contemporary Islamic scholars. Therefore, a study of the need for Arabic language use was conducted among groups.

This study is in line with the views of Iwai et. al (1999) stated that the analysis of these requirements refers to the activities undertaken to obtain information or data to form the basis for developing a curriculum that meets the needs of a group of students. These requirements are prioritized to make the results more effective. It is seen in line with Tu'aimah's (1989) view that teaching for a specific purpose for specific groups must have specific language content and skills in order to achieve comprehensive learning outcomes.

There are number of studies that have been carried out among them by Khairun Nisaa Mohd et. al (2017) states that the development of Arabic for worship (ibadah) purposes in Malaysia can also be seen through the emergence of Arabic language textbooks that focus on the purpose of worship (ibadah). The purpose of worshipping here is to include aspects of the 
Qur'anic verses, the Prophet's Hadith, recitations in prayers, remembrance, prayers, as well as recitations in Hajj and Umrah. Among the books or modules for learning Arabic are the Arabic Language Study Guide for Pilgrims \& Umrah (2009) by Muhammad Sabri Sahrir, Teaching Arabic Language through the Quran (2010) by Sohair Abdel Moneim Sery, Arabic for Worship (ibadah) activities (2010) by Mohd Puzhi Usop and Mohammad Seman and more. The purpose of understanding the Arabic language is to understand prayers, remembrance, recitation of prayers and worship (ibadah) in order to achieve the perfect Islamic teachings. Whereas economic needs mean the need for transactions to avoid misunderstandings or fraud.

Ab. Halim Mohamad (2009) conducted a study on the level of Arabic language use among Public Higher Education Institutions (HEIs) students and barriers to Arabic language proficiency. The study was conducted on 130 Bachelor students in Arabic in 5 HEIs which is UPM, UKM, UM, UIAM and USIM. The results show that the use of Arabic among local high school students is low, both in and out of the classroom. The low level of Arabic usage was due to external and internal factors. Internal factors are students' feelings towards the language being learned such as shame, insecurity, fear, not enthusiasm and so on. The findings of this study have practical implications for techniques and Arabic teaching methods in order to increase the use of Arabic among students.

Mohammad Najib Jaffar et. al (2013) conducted a study of 150 second year students and three undergraduate programs in Arabic and Communication to study Arabic for Religious Purpose (BAUTA) using the questionnaire. The findings of the study found that Bachelor of Arabic Language and Communication students at USIM were largely in agreement with the need to study BAUTA to understand Islam better by referring directly to the main sources of the Quran and al-Hadith without relying solely on translation sources.

Mohd Shahrizal Nasir et. al (2015) has reviewed perceptions of Arabic language learning for the purpose of worship (ibadah) among the civilian Muslim community in Malaysia. The survey was conducted through a questionnaire posted on the Facebook social page involving 616 respondents across Malaysia. The study also found that the majority of the public recognized the importance of Arabic language learning for the Muslim community in particular for understanding basic reading in worship (ibadah). Many of the respondents attributed elements of worship (ibadah) to Arabic language learning such as Quranic verses and hadiths, ma'thur recitation and the use of Quranic interpretations. In fact, some of the respondents emphasized the need to learn Arabic fushah (bahasa rasmi) which is indeed used in performing religious deeds.

Mohammad Taqiuddin Mohamad et. al (2012) found that the pre-missionary approach required that preachers go to the people calling to preach. Instead, through this medium of Islamic banking, the implementation of the preaching can be done whereby the target audience comes to preach, meaning the whole community comes to Islamic banks to meet the financial needs of individuals, families, businesses, institutions and even the government. . In this study, many Islamic or Arabic terms are used that emphasize the importance of basic knowledge of Arabic in dealing with Islamic banking.

Najjah Salwa Abd Razak et. al (2015) stated the need to create an appropriate Arabic language course for the Malaysian Armed Forces (ATM) in particular the Armed Forces Religious Corps (KAGAT), especially in official assignments such as Haj operations in Saudi Arabia under the Pilgrimage Fund (TH). This study aims to look at the perspectives of 
KAGAT members on the use of Arabic in the hajj operation and to analyze the need for language as a first step in establishing a syllabus for them. This study is a multicenter case study using interviews as well as triangulation for data validity. Studies have found that ATMs use Arabic in various situations in which they need to perform basic tasks such as logistics and placement management, customer service management and emergency and welfare patrols. They also use Arabic in the context of non-verbal assignments as document translators. Studies have also found that the use of Arabic language including the need for language provides detailed information on the direction of planning and the construction of language lessons. Therefore, this study reinforces the views and findings of previous studies on the importance and credibility of language needs analysis procedures to obtain information needed for programs, courses, and language lessons.

Mohamad Fitri Mohamad Yusoff and Zaitul Azma Zainon Hamzah (2014) in their study also looked at the use of the Malay language as the medium of discourse of the Islamic financial system (Muamalat) that developed in the conventional economic system undergoing a process of ups and downs. It is seen through an annual report of Bank Islam Malaysia Berhad (BIMB) starting from its inception in 1984 to 1997 using a bilingual format, namely Bahasa Melayu and English. The social practice of this practice is found to have influenced the use of language in particular in terms of the use of words / terms. Results found is the Malay words / terms are not uncommon, the pure Arab words / terms, and the Arab - Malay words / terms in the review text operations managing director of Bank Islam Malaysia Berhad (BIMB) Malay language. This means that the use of the Malay words / terms are not uncommon, the Arabic word / term and Arab- Malay genuine words / terms are not made freely but aim to support and reinforce the concept of courtesy which is practically in social Muamalat.

\section{Methodology}

This study uses document analysis method and quantitative research method using questionnaire instrument. The study used questionnaire form and was given to 60 Islamic Finance ISM students at Sultan Azlan Shah University, Kuala Kangsar. The questionnaire is divided into three sections. Part One looks at the background of respondents such as gender, age, semester, and Arabic language learning experience. Part Two looks at the knowledge of Arabic language among Islamic Finance ISM students using SS-shaped answers S) strongly agree, TS) disagree and STS) strongly disagree. Part Three looks at the need for Arabic language among Islamic Finance ISM students using the "yes or no" answer.

The data collected from the questionnaire submitted to the survey respondents will be analyzed. The findings from the analysis will be summarized and identified the aspects of the importance and needs of the Arabic language to overcome the problems and weaknesses inherent in understanding the terms of the practice.

\section{Results and Findings}

This study uses document analysis method and questionnaire form method. The findings from the document analysis method are intended to look at the relevance of the PBA6013: Arabic Language for Muamalat courses used by Bachelor of Islamic Finance students at USAS. Among the topics in the course are: 


\begin{tabular}{|c|c|}
\hline NO & COURSE TOPICS \\
\hline 1. & $\begin{array}{l}\text { AL-HIWAR FI AL-MUASSASAH AL-TIJARIYYAH } \\
\text { i) The mastery of the Arabic word. } \\
\text { ii) Word divisions. } \\
\text { - } \text { - Introduction to Isim, Fi'il and Harf. }\end{array}$ \\
\hline 2. & $\begin{array}{l}\text { AL-HIWAR FI AL-BANK } \\
\text { i) The mastery of the Arabic word.. } \\
\text { ii) Mudhakkar dan Muannath } \\
\text { • Signs Mudhakkar dan Muannath } \\
\text { iii) Alif Lam Syamsiyah dan Qomariyah } \\
\text { - Distribution of Alif Lam Syamsiyah and Qomariyah }\end{array}$ \\
\hline 3. & $\begin{array}{l}\text { AL-AYAAT AL-QURANIYYAH AN AL-MUAMALAT } \\
\text { i) The mastery of the Arabic word. } \\
\text { ii Mufrad, Muthanna dan Jama' nouns } \\
\text { - Division and signs of Mufrad, Muthanna and Jama', } \\
\text { nouns }\end{array}$ \\
\hline 4. & $\begin{array}{l}\text { AL-AHAADITH AL-NABAWIYYAH AN AL- } \\
\text { MUAMALAT } \\
\text { i) The mastery of the Arabic word. } \\
\text { ii) Nakirah and Ma'rifah } \\
\text { - Introduction to Nakirah and Ma'rifah }\end{array}$ \\
\hline 5. & $\begin{array}{l}\text { AL-ISTITHMAR } \\
\text { i) The mastery of the Arabic word.. } \\
\text { ii) Dhamir } \\
\text { - Introduction and division of Dhamir } \\
\text { - Dhamir Munfasil and Muttasil }\end{array}$ \\
\hline 6. & $\begin{array}{l}\text { AL-HALAL WA AL-HARAM FI AL-MUAMALAH } \\
\text { i) The mastery of the Arabic word. } \\
\text { ii) Ism al-Isyarah } \\
\text { - Introduction and division of Ism al-Isyarah }\end{array}$ \\
\hline 7. & $\begin{array}{l}\text { TA'MIN } \\
\text { i The mastery of the Arabic word.. } \\
\text { ii) Ism al-Mawsul } \\
\text { - Introduction and division of Ism al-Mawsul }\end{array}$ \\
\hline 8. & $\begin{array}{l}\text { BAYT AL-MAL } \\
\text { i) The mastery of the Arabic word. } \\
\text { ii) Fi'il } \\
\text { - Introduction and division of Fi'il Madhi and Mudhari, }\end{array}$ \\
\hline 9. & $\begin{array}{l}\text { AL-SADAQAH WA AL-ZAKAH WA AL-ATIYYAH } \\
\text { i) The mastery of the Arabic word. } \\
\text { ii) Harf Jar } \\
\text { - Introduction and division of Harf Jar }\end{array}$ \\
\hline
\end{tabular}




\begin{tabular}{|c|l|}
\hline 10. & $\begin{array}{l}\text { AL-RAHN } \\
\text { i) The mastery of the Arabic word. } \\
\text { ii) Zarf } \\
\bullet \quad \text { Introduction to Zarf al-Zaman and Zarf al-Makan }\end{array}$ \\
\hline 11. & $\begin{array}{l}\text { AL-UMALAT AL-ALAMI } \\
\text { i) The mastery of the Arabic word. } \\
\text { ii) Adjectives } \\
\bullet \quad \text { Introduction and features of Adjectives }\end{array}$ \\
\hline
\end{tabular}

Subsequent findings from the survey questionnaire were analyzed with frequency and percentage statistics. In this section, the findings of the study will discuss the results of the analysis and present the findings of the research conducted from the questionnaire form distributed and filled out by the respondents.

\section{First Part}

About 60 Islamic Finance ISM students at USAS were involved in responding to this Arabic language study. Descriptions of the respondents' background analysis involving aspects of gender, age, semester and level of Arabic learning are presented in the table below:

Table 1: Respondents' Background

\begin{tabular}{|c|c|c|c|c|}
\hline NO & & INFORMATION & Frequency & $\%$ \\
\hline \multirow{2}{*}{ (a) } & \multirow{2}{*}{ Gender } & Male & 33 & $55 \%$ \\
\hline & & Female & 27 & $45 \%$ \\
\hline \multirow{3}{*}{ (b) } & \multirow{3}{*}{ Age } & $<-20$ & 10 & $17 \%$ \\
\hline & & $21-24$ & 43 & $72 \%$ \\
\hline & & $25->$ & 7 & $11 \%$ \\
\hline \multirow{3}{*}{ (c) } & \multirow{3}{*}{ Semester } & Sem $<-3$ & 27 & $45 \%$ \\
\hline & & Sem $4-5$ & 22 & $37 \%$ \\
\hline & & Sem 6 - > & 11 & $18 \%$ \\
\hline \multirow{2}{*}{ (d) } & \multirow{2}{*}{$\begin{array}{c}\text { Arabic } \\
\text { Language } \\
(\mathbf{B A})\end{array}$} & Learn BA & 42 & $70 \%$ \\
\hline & & Never Learn BA & 18 & $30 \%$ \\
\hline \multirow{4}{*}{ (d.1) } & \multirow{4}{*}{$\begin{array}{c}\text { Learning } \\
\text { Stages of } \\
\text { BA - } 42\end{array}$} & Primary School & 11 & $26 \%$ \\
\hline & & PMR & 14 & $33 \%$ \\
\hline & & SPM & 13 & $31 \%$ \\
\hline & & others & 4 & $10 \%$ \\
\hline
\end{tabular}


The findings showed that out of 60 respondents, there were $33(55 \%)$ male respondents, while the remaining $27(45 \%)$ were female respondents. There were no significant differences in respondents' gender selection. This study is to look at the Arabic language requirements of Islamic Finance ISM students at USAS. Selected genders need to be balanced so that the answer they receive is not in favor of only one gender.

Based on the survey results, out of the 60 respondents surveyed, $10(17 \%)$ respondents were under the age of 20. The respondents aged 21 to 24 were $43(72 \%)$ and the rest were 25 and above only $7(11 \%)$.

The study also found that the majority of respondents were those in semester 1 to semester 3 were $27(45 \%), 4$ to semester 5 were $22(37 \%)$ and $11(18 \%)$ were students in semester 6 and above.

The results showed that 60 respondents $(42 \%)$ consisted of respondents who had learned Arabic, while the remaining 18 (30\%) were respondents who had never studied the Quran. 11 (26\%) of the 42 people who studied Arabic were in primary school, 14 (33\%) in PMR, 13 $(31 \%)$ in SPM and $4(10 \%)$ studied. Arabic through another level.

\section{Part Two}

Table 2: Knowledge of Arabic Language

\begin{tabular}{|c|c|c|c|c|c|c|}
\hline \multirow{2}{*}{ NO } & \multirow{2}{*}{ CONTENTS } & & \multicolumn{4}{|c|}{ SCALE } \\
\hline & & & SS & $\mathbf{S}$ & TS & STS \\
\hline \multirow{2}{*}{ 1) } & \multirow{2}{*}{$\begin{array}{l}\text { I obtained Arabic } \\
\text { language information in } \\
\text { Islamic finance courses. }\end{array}$} & FREQUENCY & 6 & 35 & 13 & 6 \\
\hline & & PERCENTAGE & $10 \%$ & $58.3 \%$ & $21.7 \%$ & $10 \%$ \\
\hline \multirow{2}{*}{ 2) } & \multirow{2}{*}{$\begin{array}{l}\text { I often write and read in } \\
\text { Arabic. }\end{array}$} & FREQUENCY & 5 & 15 & 30 & 10 \\
\hline & & PERCENTAGE & $8.3 \%$ & $25 \%$ & $50 \%$ & $16.7 \%$ \\
\hline \multirow{2}{*}{ 3) } & \multirow{2}{*}{$\begin{array}{l}\text { I learned Arabic through } \\
\text { scholarly reading. }\end{array}$} & FREQUENCY & 7 & 22 & 21 & 10 \\
\hline & & PERCENTAGE & $11.7 \%$ & $36.7 \%$ & $35 \%$ & $16.6 \%$ \\
\hline \multirow{2}{*}{ 4) } & \multirow{2}{*}{$\begin{array}{l}\text { I learned Arabic through } \\
\text { the Internet. }\end{array}$} & FREQUENCY & 7 & 22 & 14 & 17 \\
\hline & & PERCENTAGE & $11.7 \%$ & $36.7 \%$ & $23.3 \%$ & $28.3 \%$ \\
\hline \multirow{2}{*}{ 5) } & \multirow{2}{*}{$\begin{array}{l}\text { I like the Arabic PDPC } \\
\text { which uses animation. }\end{array}$} & FREQUENCY & 10 & 22 & 15 & 13 \\
\hline & & PERCENTAGE & $16.7 \%$ & $36.7 \%$ & $25 \%$ & $21.7 \%$ \\
\hline \multirow{2}{*}{ 6) } & \multirow{2}{*}{$\begin{array}{l}\text { I use Arabic dictionaries } \\
\text { to understand Arabic. }\end{array}$} & FREQUENCY & 11 & 27 & 13 & 9 \\
\hline & & PERCENTAGE & $18.3 \%$ & $45 \%$ & $21.7 \%$ & $15 \%$ \\
\hline \multirow{2}{*}{ 7) } & \multirow{2}{*}{$\begin{array}{l}\text { I can understand Arabic } \\
\text { through reading the }\end{array}$} & FREQUENCY & 9 & 29 & 14 & 8 \\
\hline & & PERCENTAGE & $15 \%$ & $48.3 \%$ & $23.3 \%$ & $13.4 \%$ \\
\hline
\end{tabular}


Quranic verses and

hadiths

I understand the terms

8)

Wadiah, Bai 'Bithaman

$\begin{array}{lllll}\text { FREQUENCY } & 16 & 26 & 9 & 9\end{array}$

Ajil, Bai' Al-'Inah, Al-

Ijarah etc.

$\begin{array}{lllll}\text { PERCENTAGE } & 26.7 \% & 43.3 \% & 15 \% & 15 \%\end{array}$

I learned Arabic through

9) Islamic finance when I learned Arabic.

FREQUENCY

10

29

15

6

PERCENTAGE $\quad 16.7 \% \quad 48.3 \% \quad 25 \% \quad 10 \%$

I learned Arabic through

10) the application of Arabic in life.

FREQUENCY

8

20

19

13

PERCENTAGE $\quad 13.3 \% \quad 33.3 \% \quad 31.7 \% \quad 21.7 \%$

The second section of the survey results in table 3 in the first item above found that $10 \%$ of the respondents strongly agreed and 58.3\% agreed that they obtained Arabic language information in Islamic finance courses.

The use of Arabic was based on item 2 obtained from respondents who indicated 50\% disagree and $16.7 \%$ strongly disagree that they regularly write and read in Arabic.

The study also stated that $35 \%$ disagree and $16.6 \%$ strongly disagree that learning Arabic should be through scholarly reading. Students also stated that $23.3 \%$ of them disagree and 28.3\% strongly disagree that Arabic language learning should be via the Internet. This indicates that students want to learn in various situations. The Arabic language study too, suggested using animation based on item 5 which indicated that $16.7 \%$ agreed and $36.7 \%$ strongly agreed that PDPC system use animation would keep up with current trends.

The use of dictionaries in Arabic language learning was required based on $18.3 \%$ of respondents and $45 \%$ of respondents who agreed to use dictionaries to find the meaning of words they did not understand.

The average among respondents also stated that they were able to understand Arabic through reading the Quranic and Hadith texts based on item 7 which showed 15\% strongly agree and $48.3 \%$ agree. The study found that Islamic finance ISM students $26.7 \%$ strongly agree and $43.3 \%$ agree that they understand the terms Wadiah, Bai 'Bithaman Ajil, Bai' Al-'Inah, AlIjarah and others. A total of $16.7 \%$ agreed and $48.3 \%$ agreed that they could master Arabic through Islamic finance when studying Arabic.

Respondents also stated that they could not master Arabic through the application of Arabic in everyday life based on the percentage of $31.7 \%$ disagree and $21.7 \%$ strongly disagree because in their daily life, they needed the Arabic-speaking environment in order to assist them in mastering the language.

The results of this study are in line with Rim Adil al-Turk's (2011) suggestion that language activities can shape the language environment and enhance language skills for students 
especially non-native speakers of the ljanguage. The results of this study also highlight the importance of Arabic language in studying the financial and banking system in Malaysia.

\section{Part 3}

Table 3: Arabic Language Learning Needs

\begin{tabular}{|c|c|c|c|c|}
\hline NO & QUESTION & & Frequency & $\%$ \\
\hline \multirow{2}{*}{ 1) } & \multirow{2}{*}{$\begin{array}{l}\text { Is the use of Arabic important in Islamic } \\
\text { finance and muamalat business? }\end{array}$} & Yes & 39 & $65 \%$ \\
\hline & & No & 21 & $35 \%$ \\
\hline \multirow{2}{*}{ 2) } & \multirow{2}{*}{$\begin{array}{l}\text { Should Arabic be commercialized } \\
\text { among the general public? }\end{array}$} & Yes & 39 & $65 \%$ \\
\hline & & No & 21 & $35 \%$ \\
\hline \multirow{2}{*}{ 3) } & \multirow{2}{*}{$\begin{array}{l}\text { Does Arabic need to be featured in IPTA } \\
\text { / IPTS as a reference language? }\end{array}$} & Yes & 41 & $68.3 \%$ \\
\hline & & No & 19 & $31.7 \%$ \\
\hline \multirow{2}{*}{ 4) } & \multirow{2}{*}{$\begin{array}{l}\text { Does the use of modern technology help } \\
\text { to understand Arabic? }\end{array}$} & Yes & 40 & $66.7 \%$ \\
\hline & & No & 20 & $33.3 \%$ \\
\hline \multirow{2}{*}{ 5) } & \multirow{2}{*}{$\begin{array}{l}\text { Is learning a Fiqh course in Arabic a } \\
\text { necessity? }\end{array}$} & Yes & 17 & $28.3 \%$ \\
\hline & & No & 43 & $71.7 \%$ \\
\hline \multirow{2}{*}{ 6) } & \multirow{2}{*}{$\begin{array}{l}\text { Are relevant banking terms used in } \\
\text { Arabic? }\end{array}$} & Yes & 37 & $61.7 \%$ \\
\hline & & No & 23 & $38.3 \%$ \\
\hline \multirow{2}{*}{ 7) } & \multirow{2}{*}{$\begin{array}{l}\text { Is the Arabic language widely used } \\
\text { during the learning process in the } \\
\text { Islamic Finance ISM program? }\end{array}$} & Yes & 35 & $58.3 \%$ \\
\hline & & No & 25 & $41.7 \%$ \\
\hline \multirow[b]{2}{*}{ 8) } & \multirow{2}{*}{$\begin{array}{l}\text { Is there a need for a specific Arabic } \\
\text { language study guide or module to study } \\
\text { for Islamic finance students? }\end{array}$} & Yes & 45 & $75 \%$ \\
\hline & & No & 15 & $25 \%$ \\
\hline
\end{tabular}

Based on the survey results in table 3 above, $65 \%$ agree that the use of Arabic is important in Islamic finance and muamalat business and $65 \%$ say that Arabic language should be commercialized among the general public. The study also found that $68.3 \%$ of respondents said Arabic should be featured in the IPTA / IPTS as their reference language.

The study also showed that $66.7 \%$ agreed that using modern technology could help them understand Arabic. However, $71.7 \%$ of respondents said they did not agree that the Fiqh Muamalat course used in Arabic was for learning. The survey found that $61.7 \%$ of respondents agreed to use the term banking in Arabic. 
In addition, 58.3\% stated that the term Arabic was widely used during the learning process in the Islamic Finance ISM program and only $75 \%$ of respondents stated that they needed manual or Arabic language learning modules specifically for mentoring for finance or banking students.

\section{Conclusion}

This study aims to identify the importance and needs of Arabic language learning among Islamic finance students. The questionnaire was used as the instrument of this study. This study covers the knowledge and use of Arabic language by respondents among students at USAS.

Studies have found that the use Arabic language among students in particular the Islamic Finance ISM is not widely used in their courses, but it is used to understand Arabic terms in the contracts and terms used in their learning.

The use of banking machines and smart technologies using Arabic is also seen to help and facilitate Middle Eastern investors in Malaysia as they use Arabic extensively in everyday life. Banking is now easier to do online because it saves you time and energy. To date, there have been approximately 11 smart applications in teknowang (financial technology) that have been able to replace the six functional clusters of financial tradition involving insurance, deposits and loans, fund financing, investment, market provision and payment systems.

Based on this study, the study of requirements of Arabic language learning among students helped the researcher to formulate a syllabus that corresponds to the level of student need in the field of study. Therefore, it is imperative to design Arabic curriculum or modules for the purpose of practice so that it can help students to understand learning using Islamic financial terms.

\section{References}

Ab. Halim Mohamad. (2009). Tahap Komunikasi dalam Bahasa Arab dalam Kalangan Pelajar Sarjana Muda Bahasa Arab di IPTA Malaysia. Journal of Islamic and Arabic Education 1(1) 2009, 1-14.

Iwai, Tomoko Kondo, K, Limm, S.J.D, Rey, E.J., Shimizu, H, and Brown J.D. (1999). Jappanese Language Needs Analysis. http://www.nflrc.hawaii.edu

Khairun Nisaa Mohd, Nor Zahidah Ahmad dan Nonglaksana Kama. (2017). Kajian Kes Keperluan Bahasa Arab dalam Kalangan Jemaah Haji dan Umrah Malaysia dari Sudut Pandang Mutawwif-Mutawwif Syarikat Andalusia. International Journal of Religion Research in Education, 1 (1), 34 -40.

Mohamad Fitri Mohamad Yusoff dan Zaitul Azma Zainon Hamzah. (2014). Istilah Melayu dan Arab dalam Wacana Muamalat. Jurnal Bahasa, 14 (1): 93-118.

Mohammad Najib Jaffar, Kirembwe Rashid Abdul Hameed dan Hishomuddin Ahmad. (2013). Bahasa Arab untuk Tujuan Agama: Analisis Keperluan Pelajar Sarjana Muda Bahasa Arab dan Komunikasi di Universiti Sains Islam Malaysia. 'Uium Islamiyyah Journal. Vol. 10: 19-29.

Mohammad Taqiuddin Mohamad, Joni Tamkin Borhan dan Mohd Afifuddin Mohamad. (2012). Potensi perbankan Islam sebagai medium baru perkembangan dakwah di Malaysia. Jurnal Usuluddin, (35): 117-142.

Mohd Puzhi Usop dan Mohammad Seman. (2010). Bahasa Arab untuk Ibadah. Kuala Lumpur: Telaga Biru Sdn Bhd. 
Mohd Shahrizal Nasir, Muhammad Sabri Sahrir dan Mohd Firdaus Yahaya. (2015). Tinjauan Persepsi Pembelajaran Bahasa Arab untuk Tujuan Ibadah Sebagai Satu Keperluan bagi Masyarakat Muslim Awam di Malaysia. Asia Pacific Journal of Educators and Education, Vol. 30: 51-72.

Mohd Soberi Awang. (2011). Al-Hayah: Kamus Istilah Muamalat. Kuala Lumpur: Telaga Biru Sdn Bhd.

Muhammad Sabri Sahrir. (2009). Panduan Belajar Bahasa Arab untuk Jemaah Haji \& Umrah. Kuala Lumpur: Telaga Biru Sdn Bhd.

Najjah Salwa Abd Razak, Ahmad Munawar Ismail dan Kaseh Abu Bakar. (2015). Analisis Keperluan Bahasa Arab untuk Tugasan Rasmi Anggota Tentera Malaysia di Negara Arab. International Journal of Language Education and Applied Linguistics (IJLEAL). Vol. 3: 79-90.

Pabiyah Hajimaming dan Che Radiah Mezah. (2010). Penekanan Aspek Semantik Kata Pinjaman Arab dalam Bahasa Melayu semasa Pengajaran Bahasa Arab. Pengajaran Bahasa Arab Siri 1. Serdang:Penerbit Universiti Putra Malaysia. 33-41.

Rim Adil al-Turk. (2011). Iktisab Maharah Muhadathah li al-Natiqin bi Ghayr al-'Arabiyyah bi Istiratijiyyah Lu'biyyah: Tamthil Adwar Namuzajan. Prosiding Seminar Antarabangsa Pengajaran Bahasa Arab 2011, 310-319.

Sohair Abdel Moneim Sery. (2010). Pengajaran Bahasa Arab Menerusi Al-Quran. Batu Caves: Pustaka Haji Abdul Majid.

Tu'aimah, Rusydi Ahmad. (1989). Ta'lim al-Arabiyyah li Ghair Natiqin biha Manahijuhu wa Asalibuhu. Rabat: ISES. 